\title{
SHEATHNEMA INDICUM GEN. ET SP. NOV. A NEW SOOTY MOLD FUNGUS FROM NORTHERN WESTERN GHATS, INDIA
}

\author{
Rashmi Dubey ${ }^{1} \&$ Neelima Azhamchalil Moonnambeth ${ }^{2}$ \\ 1,2 Botanical Survey of India, Western Regional Centre, 7, Koregaon Road, Pune, Maharashtra 411001, India \\ ${ }^{1}$ dr.rashmidubey@gmail.com (corresponding author), ${ }^{2}$ imaveen@gmail.com
}

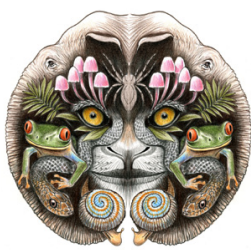

ISSN 0974-7907 (Online) ISSN 0974-7893 (Print)

OPEN ACCESS
Abstract: A new genus and species Sheathnema indicum was collected from the leaves and other aerial parts of Pandanus tectorious Sol. ex Park. from the forest areas of Sawantwadi Taluka, Sindhudurg District, Maharashtra. Morphologically this new genus is a synnematous fungus and can be easily differentiated from similar genera such as, Spiropes, Dematophora, Tharoopama, Phaeoisariopsis, Graphium, Leptographium and various other synematous forms in having a dark brown infertile sheath completely covering the synemata at the young stage and partially covering the fruiting body at the mature stage. Besides this it can also be differentiated from other allied genera in having 2-3 septate hyaline to sub hyaline conidia. A description, illustrations and comparison with other allied taxa are presented hereafter.

Keywords: Ascomycetes, new genus, morphotaxonomy, Sheath, sooty mold, Synemata.
The forests, micro habitats and tropical warm humid climate that prevail in the Western Ghats support many rare and new forms of fungi. During January 2012, surveys were conducted to explore the microbial diversity in the natural forests of Sawantwadi, situated at an altitude of $690 \mathrm{~m}$ in southern Maharashtra, which resulted in the collection of a rare fungi subsequently determined to be a new genus. The present study describes and illustrates this unusual interesting sooty mold fungus collected from the Sawantwadi Taluka of Maharashtra.

\section{MATERIAL AND MethodS}

Surface scraping of the aerial parts bearing the sooty mold fungus was taken and mounted in lactophenol
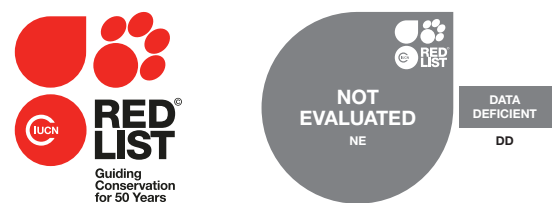

Sheathnema indicum

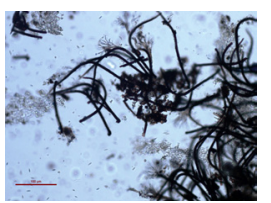

DOI: http://dx.doi.org/10.11609/JoTT.o3514.6549-55

Editor: R.K. Verma, Tropical Forest Research Institute, Jabalpur, India.

Date of publication: 26 November 2014 (online \& print)

Manuscript details: Ms \# 03514 | Received 04 February 2013 | Final received 15 September 2014 | Finally accepted 20 September 2014

Citation: Dubey, R. \& N.A. Moonnambeth (2014). Sheathnema indicum gen. et sp. nov. a new sooty mold fungus from northern Western Ghats, India. Journal of Threatened Taxa 6(12): 6549-6555; http://dx.doi.org/10.11609/JoTT.03514.6549-55

Copyright: (C) Dubey \& Moonnambeth 2014. Creative Commons Attribution 4.0 International License. JoTT allows unrestricted use of this article in any medium, reproduction and distribution by providing adequate credit to the authors and the source of publication.

Funding: Ministry of Environment and Forests, New Delhi

Competing Interest: The authors declare no competing interests.

Acknowledgements: Authors are thankful to Dr. Paramjeet Singh, Director, Botanical survey of India for providing Laboratory facilities. They are also grateful to the Head of the office, Botanical Survey of India, Western Regional Centre, Pune for his kind support and encouragement. Sincere thanks are due to Prof. C. Manoharachary, Emeritus Scientist, Osmania University, Hyderabad (AP) for identification of fungal specimen. Ministry of Environment and Forest, New Delhi is also thankfully acknowledged for financial assistance. 
cotton blue mixture for microscopic examination. For micrometric measurements slides were observed under a Nikon compound microscope (Model Nikon Eclipse 50i). For morphotaxonomic studies and photomicrographs the Nikon microscope attached with a digital camera Nikon DS Fi 1 were used. The type specimen (Holotype) was accessioned and has been deposited in Ajrekar Mycological Herbarium (AMH) Pune, India for further reference. An isotype has been deposited at the Botanical Survey of India, Pune for further reference. Morphotaxonomic comparisons were made with allied taxa. Descriptions and nomenclatural details were deposited at MycoBank <www.mycobank.org>.

\section{Sheathnema Dubey \& Moonambeth gen. nov.}

(urn:Isid:indexfungorum.org:names: 802964). (Fungi: Ascomycetes: Sheathnema) (Images 1-13)

Colony epiphyllous, dense, velvety, hyphae straight to effuse, dark blackish-brown, tufted, with large, black synematous like fruiting body occurring in association with meliolales fungi. Stroma none, setae and hyphopodia absent. Synemata dark brown, erect and curved at the apex appearing just like a boomerang and completely remains covered by a dark brown, infertile sheath at the young stage. On maturity, the upper half portion of synnemata bearing conidiophores and conidia slowly splays out and finally spreads widely in the form of a brush leaving the dark brown sheath aside. Consequently, long dark brown synnemata bearing a single, long dark brown, continuous infertile sheath casing lower half stalk forming portion of fruiting body and exposing the upper half fertile wide part bearing conidiophores and conidia are visible. Stalk is composed of numerous pale, olivaceous brown, unbranched or rarely branched parallel hyphae which progressively become free and diverge from main stalk to form the conidiophores. Conidiophores are pale brown, becoming hyaline towards the tip, macronematous, mononematous, unbranched, rarely branched in lower portion of hyphae, repeatedly having geniculations, diverging at various angles, straight, bend and curved. Conidiogenous cells polyblastic, integrated terminal or discrete, determinate, sympoidal, geniculate, smooth. Conidia acropleurogenous, single or in groups of 4-5, long, hyaline to subhyaline, mostly with three septa, clavate to sub-clavate, rounded at the apex, tapered to the base, smooth.

\section{Sheathnema indicum sp. nov. \\ Dubey \& Moonnambeth}

(urn:Isid:indexfungorum.org:names: 810081)

$$
\text { (Images 1-13) }
$$

\section{Material examined}

B.S.I. (W.C.) 200140, AMH 9599 (Holotype), BSI 132411 (Isotype), 21.i.2012, on aerial parts of Panadanus tectorius Sol. ex Park. Family Pandanaceae $16.00^{\circ} \mathrm{N}$ \& $73.75^{\circ} \mathrm{E}$, elevation $111.86 \mathrm{~m}$, Sawantwadi Taluka, Sindhudurg District, Maharashtra, India, coll. Rashmi Dubey.

Colonies dark brown, aggregated with large, black synematous fungi; sheath covers the synemata at the young stage and is up to $470 \mu \mathrm{m}$ long, $6.6-8.5 \mu \mathrm{m}$ wide near the base and 2.5-4.0 $\mu \mathrm{m}$ wide near the apex. At the mature stage the upper part of synemata bearing conidiophores and conidia slowly splay out leaving
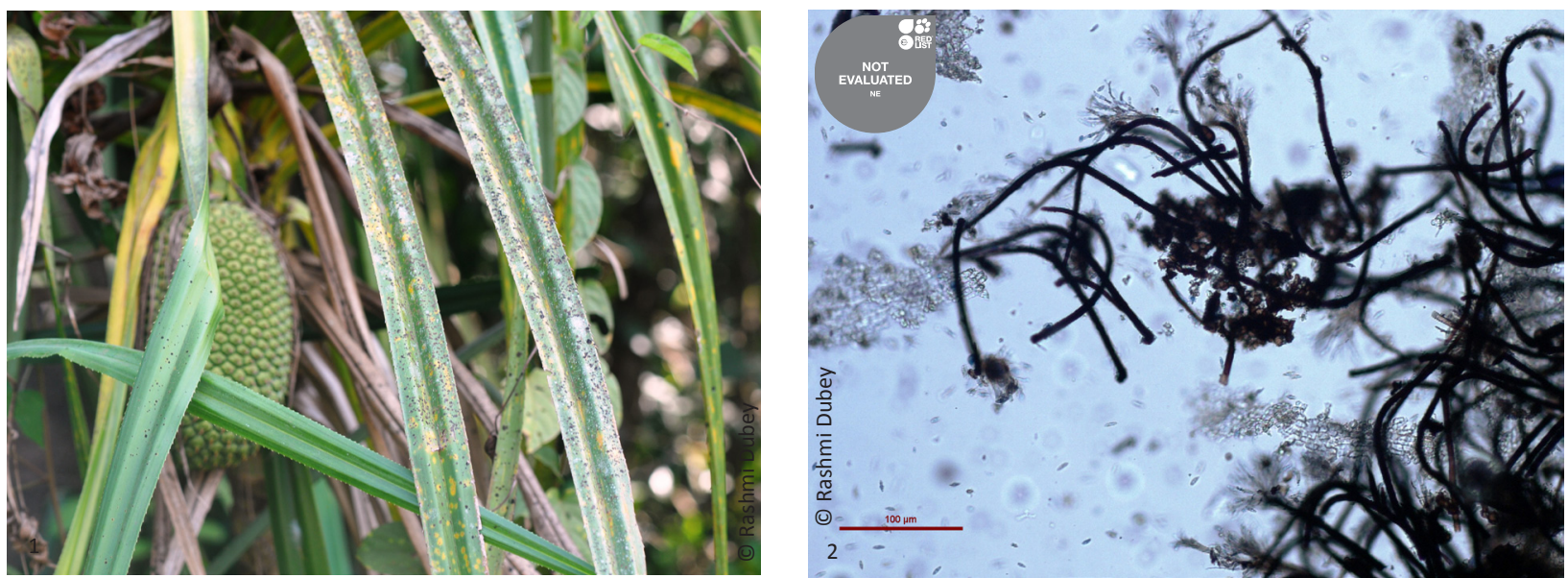

Images 1-2. Sheathnema indicum gen. et sp. nov. 1 - Diseased Plant of Pandanus tectorius Sol. Ex Park; 2- Colony (X100). 


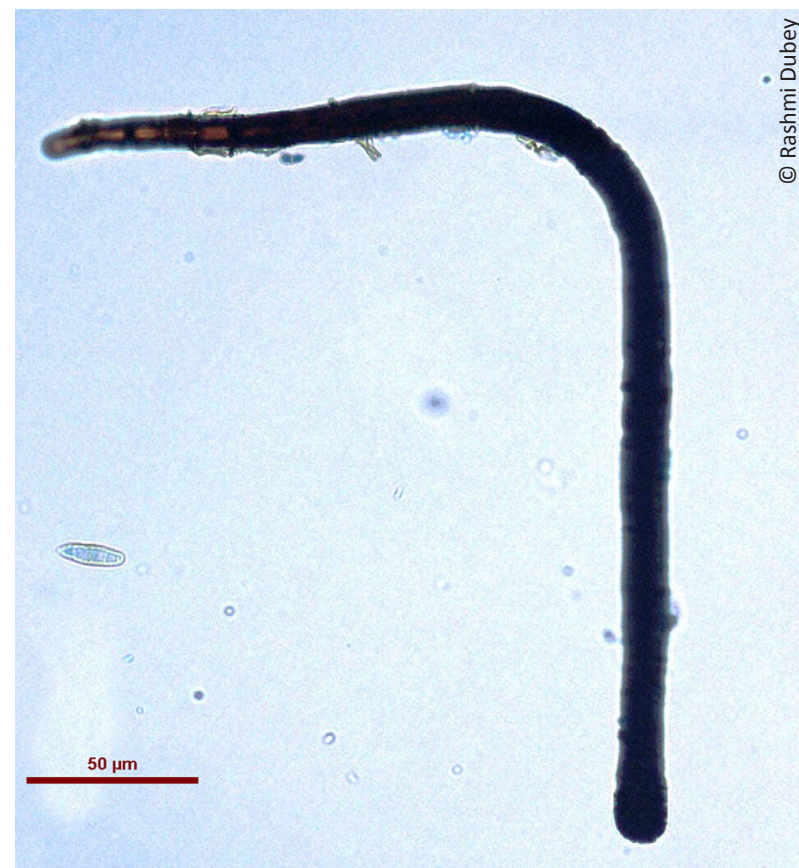

Image 3. Immature synemata entirely covered with a sheath (X200)

the sheath running aside and measures about 60-90 $x$ 36-79 $\mu \mathrm{m}$, while the lower portion of synemata with sheath forms stalk. Sheath sterile, up to $470 \mu \mathrm{m}$ long, 7-9 $\mu \mathrm{m}$ wide at the base and 2-3 $\mu \mathrm{m}$ wide at the apex, dark blackish-brown and becomes hyaline at the tip. Stalk 73.6-90.50 x 4.75-6.5 $\mu \mathrm{m}$, having numerous pale, olivaceous brown, unbranched parallel hyphae covered with a sheath; conidiophores $35.81 \times 69.55-36.4 \times 86.64$ $\mu \mathrm{m}$ in upper part of synemata, with a sheath running one side. Conidia hyaline to sub hyaline, 3-septate clavate to subclavate, rounded at the apex, tapered to the base, smooth 9.02-12.25 x 2.5-3.20 $\mu \mathrm{m}$.

Etymology: The genus name has been proposed on the basis of the presence of sheath on synematous form and species name is proposed on the name country from where it is reported.

Teleomorph: Unknown/ not observed.

Known distribution: Found in the natural forest of the northern Western Ghats.

\section{Discussion AND CONCLUSION}

Considering the synematal structure Sheathnema can be classified under family Stillbelaceae (Fr.) 1821, which accommodate certain synnematous fungus like Spiropes (Ciferri, 1955), Dematophora (Hartig, 1883), Tharoopama (Subram., 1956), Annelophragmia (Subram., 1963), Leptographium (Lagerb. \& Melin, 1927), Graphium, (Corda, 1837), Stilbum (Tode, 1790),
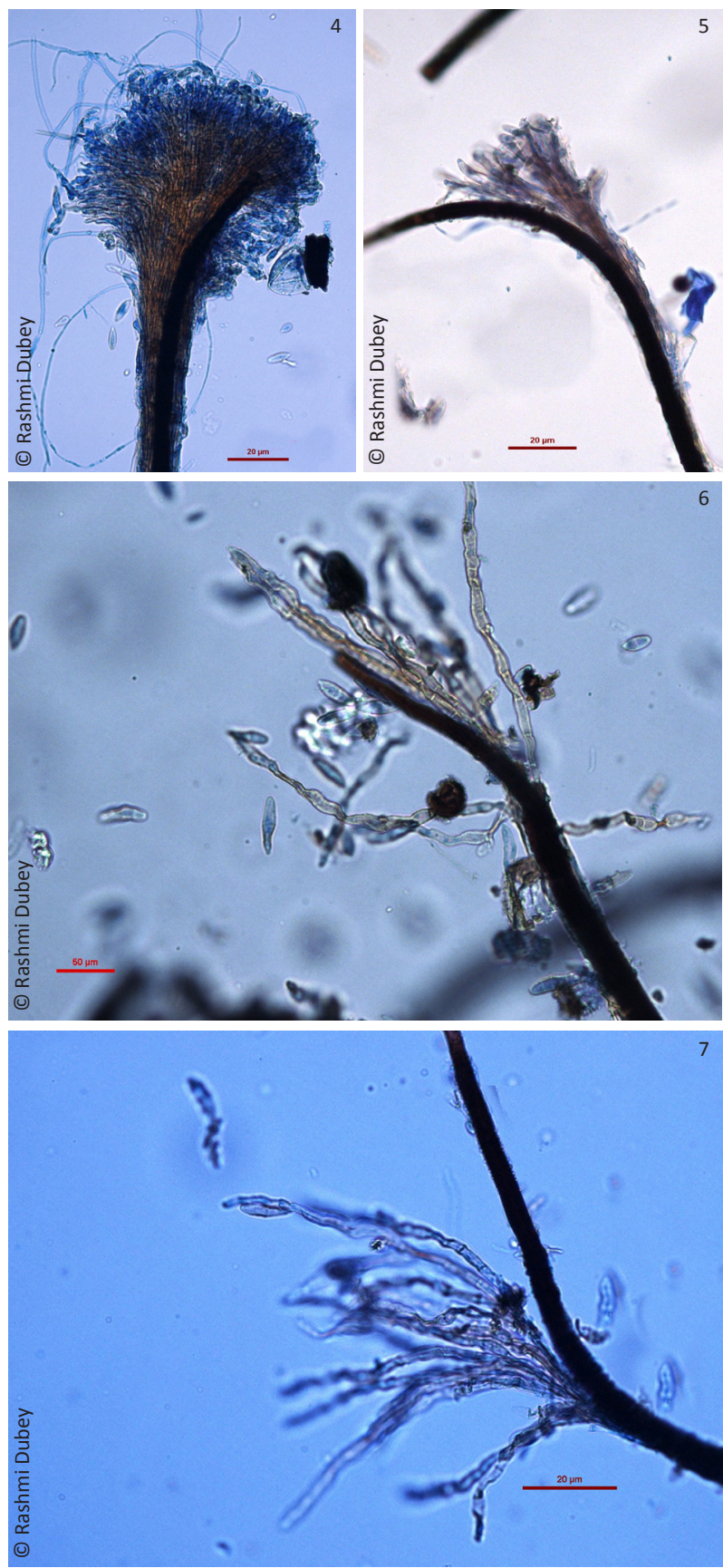

Images 4-7. Sheath detaching from upper half part of fruiting body at X400.

Phaeoisariopsis (Ferraris, 1909), Arthrobotryum (Cesati, 1854) and many more forms. However, according to the latest classification of Fungi the family Stillbelaceae has been merged with Ascomycotina (Kirk et al. 2008). After accomplishment of comprehensive studies (Seifert 1985) it was realized that the present fungus bears a unique identity in having a sheath completely covering the synemata at a young stage and partially at a mature 

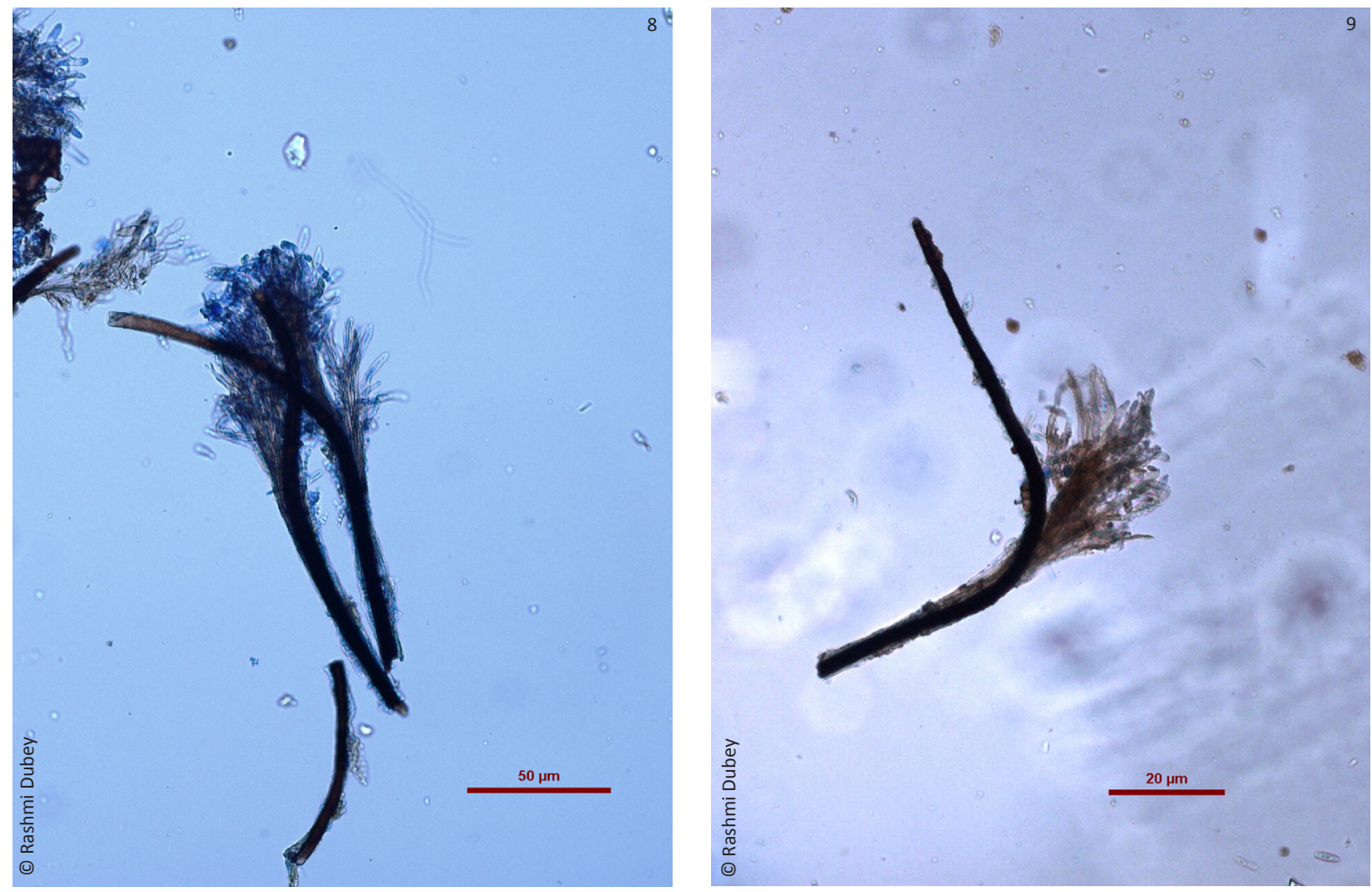

Images 8-9. Mature synemata (X200)
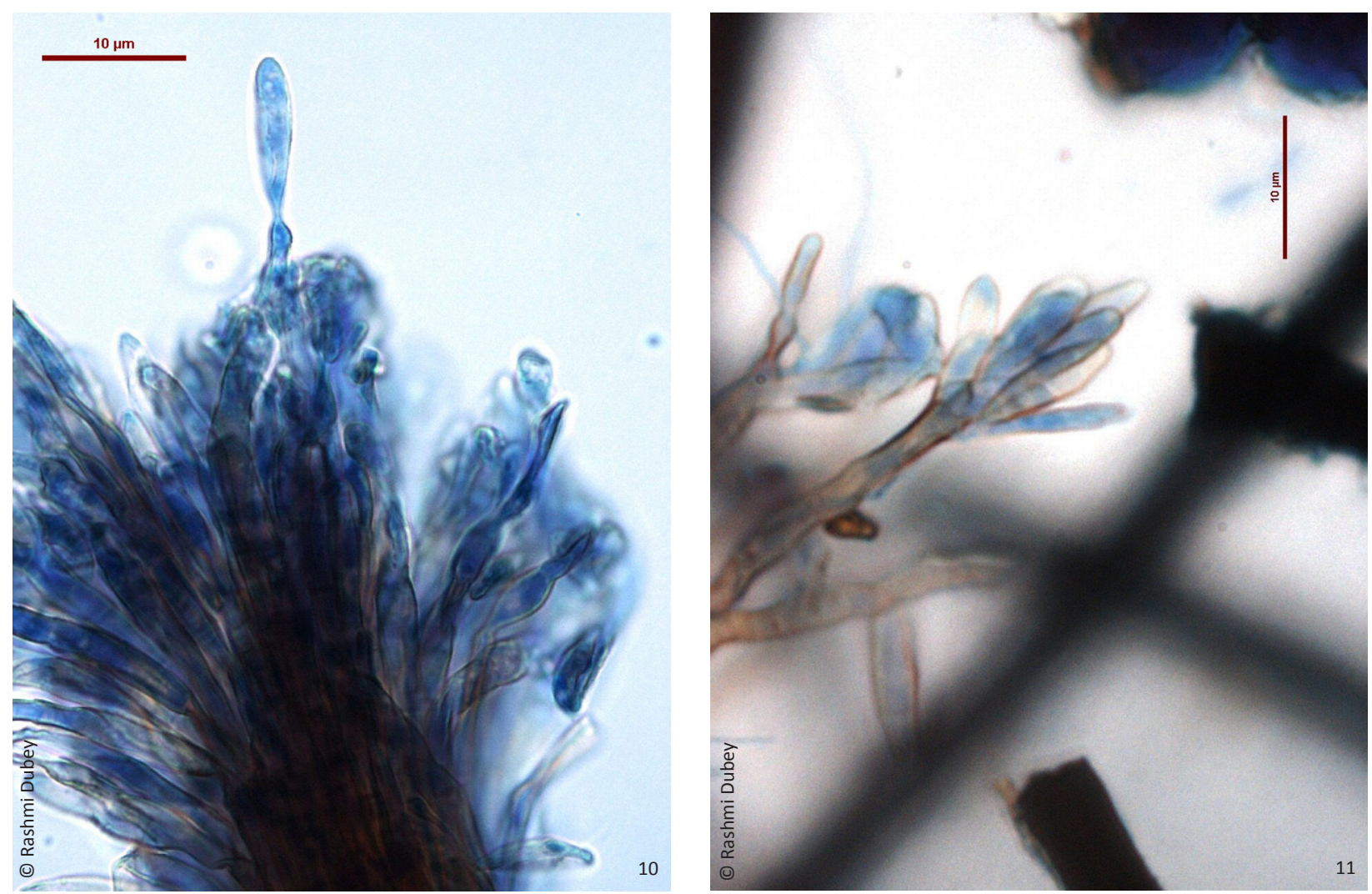

Images 10-11. Conidia and conidiophores (X1000) 


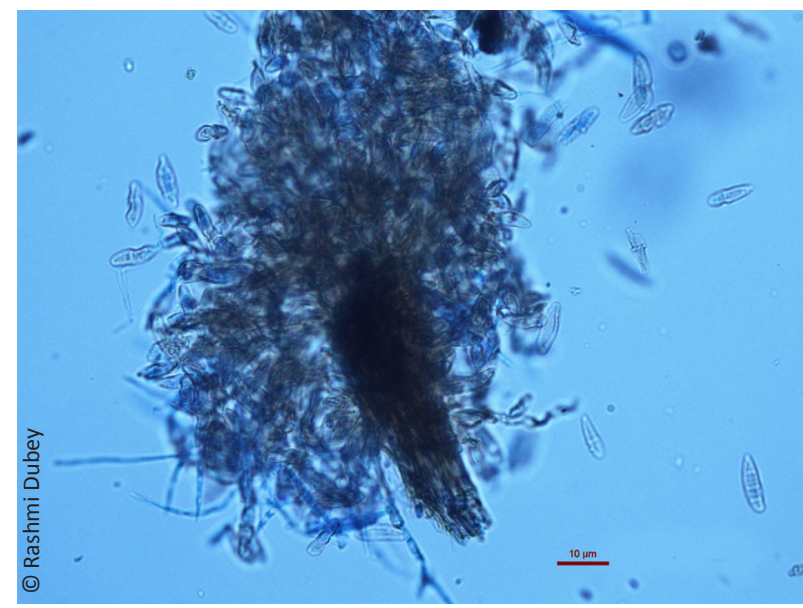

Image 12. Conidia and conidiophores X400

stage. No synematous form has been reported with a sheath and such characteristics. Stillbelaceae members like Tilachlidiopsis Auct, Polcephalomyces Kobayashi, Hisutella Pat., Solheimia Morris, Phaeostibella Honnel, Stilbum Tode, Stilbella Lindau, Stromatographium Hohnel, Phialographium Upadhyay \& Kendrick, Crinula fr., Dennisiographium Rifai, Meniosporopsis Hughes, Thozetella Kuntze, Rhizostibella Walk, Didymostilbe Henn., Eustilbum Rabenh, Coryne Nees, Dendrostilbella, Tubercularia Tode possesss amerospores with synematous fruiting body, likewise Acrostroma Seifert, 1987 and Agarwalomyces Verma \& Kamal, 1987 also possess unicellular conidia in a chain, while other genera like Didymostilbe Henn, Pseudographiella Petch, Stachycoremium Seifert, Actinostilbe Petch possess didymospores with a synematous type of fruiting body, while the proposed genus possesses phragmospores with a sheath on the fruiting body.

However, the proposed genus shows some resemblance in other morpho-taxonomic characteristics with a few synematous forms. It resembles certain other synnematous forms like Spiropes, Phaeoisariopsis, Arthrobotryum, Phragmocephala (Mason \& Hughes, 1951), Endophragmia (Duvernoy \& Maire 1920) etc., in having phragmospores. Colonies of Spiropes also occur in association with meliolales fungi, but it differs from Sheathnema in its conidiogenous cells which are with prominent scars and is cicatrized, and the conidia are also solitary, subhyaline to dark brown, whereas conidiogenous cells of Sheathnema are smooth and conidia are solitary or in groups and is clavate to subclavate. Phaeoisariopsis differs from Sheathnema in possessing cicatrized scars on conidiogenous cells and having stromata, on the contrary the conidiogenous

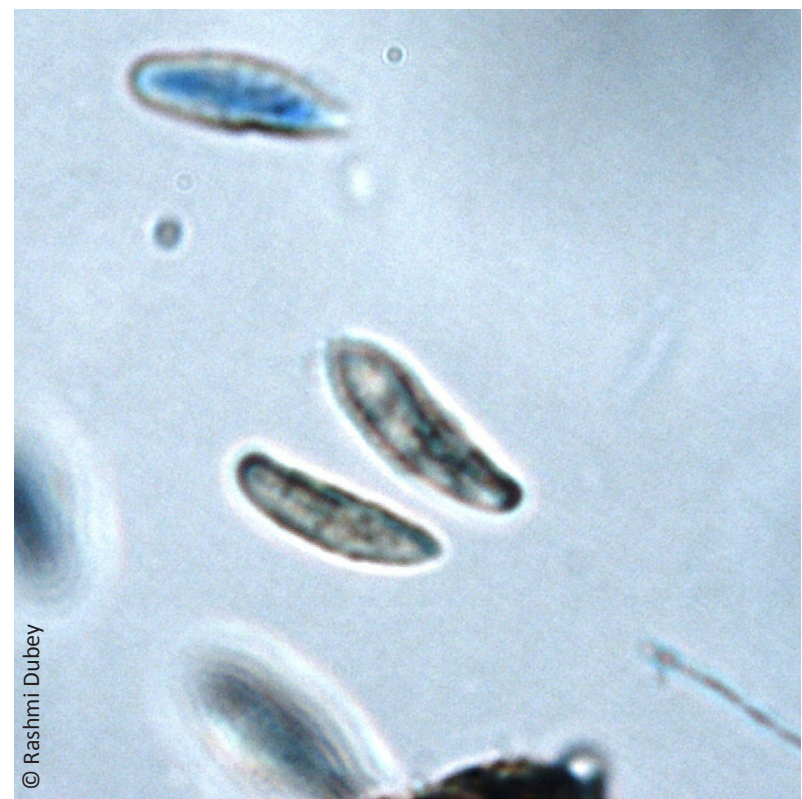

Image 13. Conidia at X1000.

cells of Sheathnema are smooth and stromata are totally absent. Arthrobotryum also has phragmospores but it differs from Sheathnema in having scattered synemata and the conidiogenous cells are percurrent with upto seven annelations, whereas synemata of Sheathnema has hyphae which are closely ad pressed along their length and splay out like a brush at the apex leaving the sheath aside and more over the conidiogenous cells are determinate in it. In Endophragmia the overall morphology resembles Sheathnema besides sheath but the conidia are 1-5 septate frequently with dark black bands at the septa. Sheathnema differs from the synnematous forms like Prathoda (Subram, 1956) and Trochospora (Moore, 1955) which have scoleospores and helicospores respectively, whereas the proposed genus has phragmospores. Sheathnema also possesses determinate conidiogenous cell which separates it from other synnematous fungi like Graphium (Corda, 1837) Leptographium (Lagerberg et al. 1927), Doratomyces (Corda, 1829) which have per current conidiogenous cells. In synematous fungi like Spiropes, Tharoopama, Dendrographium (Massee, 1892), Phaeoisaria (Hohnel, 1909) and Phaeoisariopsis the conidiophores are macronematous, synnematous, individual threads are closely adpressed along their length and splays out the apex as well as the conidiogenous cells are polyblastic, integrated and determinate, conidia are hyaline to pale olivaceous brown and smooth. The overall morphology of the above mentioned genera coincides with the morphological characteristics of Sheathnema except 
Table 1. Comparison of Sheathnema gen. nov. with other related genera.

\begin{tabular}{|c|c|c|c|c|c|c|}
\hline Genus & Fruiting body & $\begin{array}{l}\text { Sheath covering } \\
\text { fruiting body }\end{array}$ & Conidiophores & $\begin{array}{l}\text { Conidiogenous } \\
\text { cells }\end{array}$ & Conidia & References \\
\hline Spiropes & $\begin{array}{l}\text { Synematous or } \\
\text { sometimes the } \\
\text { conidiophores are } \\
\text { in loose fascicles. }\end{array}$ & Absent & Unbranched & $\begin{array}{l}\text { Polyblastic, } \\
\text { cicatrized, scars } \\
\text { numerous and } \\
\text { prominent. }\end{array}$ & $\begin{array}{l}\text { Solitary, dry, mostly } \\
\text { obclavate, fusiform } \\
\text { or oblong, smooth or } \\
\text { verruculose, 1-9 transverse } \\
\text { septate. }\end{array}$ & $\begin{array}{l}\text { Ciferri } \\
\text { (1955) }\end{array}$ \\
\hline Dermatophora & Synematous & Absent & $\begin{array}{l}\text { Simple } \\
\text { branching, with } \\
\text { geniculations. }\end{array}$ & $\begin{array}{l}\text { Ployblastic, } \\
\text { denticulate with } \\
\text { short minute } \\
\text { collar at each } \\
\text { geniculations }\end{array}$ & $\begin{array}{l}\text { One celled, ellipsoidal or } \\
\text { obovoid, colourless to } \\
\text { pale olivaceous brown, } \\
\text { 0-septate, smooth, solitary, } \\
\text { acropleurogenous. }\end{array}$ & $\begin{array}{l}\text { Hartig. } \\
(1883)\end{array}$ \\
\hline Tharoopmama & Synematous & Absent & $\begin{array}{l}\text { Verticilliate } \\
\text { branching with } \\
\text { geniculations }\end{array}$ & $\begin{array}{l}\text { Polyblastic and } \\
\text { smooth. }\end{array}$ & $\begin{array}{l}\text { One celled, hyaline, } \\
\text { globose, acrogenous. }\end{array}$ & $\begin{array}{l}\text { Subram. } \\
\text { (1956) }\end{array}$ \\
\hline Phaeoisariopsis & Synematous & Absent & Unbranched & $\begin{array}{l}\text { Polyblastic, } \\
\text { cicatrized, scars } \\
\text { thin. }\end{array}$ & $\begin{array}{l}\text { Three or more septate, } \\
\text { solitary, olivaceous } \\
\text { brown or brown, } \\
\text { smooth or verruculose, } \\
\text { acropleurogenous. }\end{array}$ & $\begin{array}{l}\text { Ferraris. } \\
\text { (1909) }\end{array}$ \\
\hline Sheathnema gen. nov. & Synematous & $\begin{array}{l}\text { Synemata completely } \\
\text { covered with a dark } \\
\text { brown sheath in } \\
\text { young stage and } \\
\text { partially covered in a } \\
\text { mature stage. }\end{array}$ & $\begin{array}{l}\text { Unbranched } \\
\text { or sometimes } \\
\text { rarely branched, } \\
\text { with repeated } \\
\text { geniculations. }\end{array}$ & $\begin{array}{l}\text { Ployblastic and } \\
\text { smooth. }\end{array}$ & $\begin{array}{l}\text { Mostly three septate, } \\
\text { hyaline, solitary or } \\
\text { in groups, clavate to } \\
\text { subclavate, rounded at the } \\
\text { apex and narrow at base } \\
\text { acropleurogenous. }\end{array}$ & - \\
\hline
\end{tabular}

the sheath and conidial structure. The characteristics of the geniculated conidiophores of Tharoopama and Dematophora are also present in Sheathnema. But detailed studies reveal that in Dematophora, the conidiogenous cells are denticulate with a short minute collar at each geniculation and more over the conidia are amerospores, ellipsoidal and ovoid, whereas in the proposed genus the conidiogenous cells are smooth and integrated along with the geniculated conidiophores and the conidia are hyaline broadly clavate to subclavate, three septate and the fruiting body is covered with a sheath. In addition to this Tharoopama also bear a resemblance with Sheathnema in having geniculations in conidiophores, but differs from it in having repeated branching in conidiophores. Phaeoisariopsis resembles Sheathnema in having unbranched or simple branching conidiophores and three septate conidia, but differs from Sheathnema in having cicatrized scars on conidiophores as mentioned earlier. In Morrisographium Morelet the conidiogenous zone in synemata is conspicuously concave and the synemata is dark with falcate, 1-3 septate conidia. In Virgatospora Finley the conidia are more than three septate and green in mass; similarly in Pseudographiella Morris the conidia are more than three septate but are yellow or orange in mass, while Ciferrioxyphium Batista \& Maia is a sooty mold fungus and the synemata is dark with 3-10 septate conidia, equally Phialoarthrobotyum Mats is a saprophytic genus with three or more septate conidia. Besides having phragmospores all the above mentioned genera totally differ from Sheathnema as the proposed genera is unique in having a sheath on synemata.

Thus, the above discussion noticeably postulates that with the exclusion of sheath, Sheathnema to some extent comes closer to Spiropes, Tharoopama, Dematophora and Pheoisariopsis in overall morphology of synemata, but Sheathnema still differs from this genera as revealed in Table 1. No synematal genus has been reported to possess a sheath covering the synemata. The major differences in the morphological characteristics with related genera warrant this taxon to be assigned to a new genus. Hence, it is proposed to be placed as a new genus named Sheathnema with type species $S$. indicum.

\section{REFERENCES}

Ciferri, R. (1955). Observations on meliolicolous Hyphales from Santo Domingo. Sydowia 9(1-6): 302.

Cesati (1854). Hedwigia, 1: Tab. 4, fig. 1. (ohne Diagnose).- Saccardo Michelia II. 32; Syll. IV, 628.

Corda, A.C.J. (1829). In Sturn, J. Deutschlands Flora Abt. III. Die Pilze Deutschlands 2: 1-136.

Corda, A.C.J. (1837). Icones. Fungorumhuscusque cognitorum 1: 18. apud J.G. Calve (Friedricum Ehrlich).

Duvernoy, A. \& R. Maire (1920). Une nouvelle Dematiee a conidies pseudoendogenes. Bulletin de la Societe Mycologique de France 36: $86-89$.

Ferraris, T. (1909). Osservazioni mycologische. Su specie del gruppo Hyphales (Hyphomycetae). Annales Mycologici 7(3): 273-286.

Fries, E.M. (1821). Systema Mycologicum, Fungorum ordines, Genera et Species, Ex officina Berlingiana 1: 1-520.

Hartig, R. (1883). Rhizomorpha (Dermatophora) necatrix n. sp. 
Untersuch. Forstbot. Inst. München 3(95): 140

Hohnel, F. von. (1909). Fragmente zur Mykologie: VI. Mitteilung (Nr. 182 bis 288). Sitzungsberichte der Kaiserlichen Akademie der Wissenschaften Math.-naturw. Klasse Abt. I 118: 275-452.

Kirk, P.M., P.F. Cannon, D.W. Minter \& J.A. Stapers (2008). Ainsworth \& Bisby's Dictionary of the Fungi". 10th edition. CAB International, Nosworthy Way, Wallingford, Oxon, UK.

Lagerberg, T., G. Lundberg \& E. Melin (1927). Biological and practical researches into Blueing in Pine and Spruce. Svenska Skogsvårdsföreningens Tidskrift 2(2-4): 145-272.

Mason, E.W. \& S.J. Hughes (1951). Phragmocephala gen. nov. Hyphomycetarum. The Naturalist London 1951: 97-105.

Massee, G.E. (1892). Notes on exotic fungi in the Royal Herbarium, Kew. Grevillea 21(97): 1-6.

Moore, R.T. (1955). Index to Helicosporae. Mycologia 47: 90-103.
Seifert, K.A. (1985). Monograph of Stilbella and some allied Hyphomycetes. Studies in Mycology 27: 1-235.

Seifert, K.A. (1987). Stromatographium and Acrostroma gen. nov.: two tropical hyphomycete genera with distinctive synnema anatomies. Canadian Journal of Botany 65(11): 2196-2201

Subramanian, C.V. (1956). Hyphomycetes - I. Journal of the Indian Botanical Society 35: 53-91.

Subramanian, C.V. (1963). On Arthrobotryum Coonnoorense. Proceedings of Indian Academy of Science 58(6)B: 348-350.

Tode, H.J. (1790). Fungi Mecklenburgenses Selecti. Fasciculus-I, Nova Fungorum Genera Complectens, Luneburgi 1: 1-47.

Verma, R.K. \& Kamal (1987). Agarwalomyces indicus gen. et sp. nov. - a fruticolous synematous hyphomycetes from Uttar Pradesh. Transactions of the British Mycological Society 89(4): 596-599. 